\title{
To What Extent Do Popular ESL Textbooks Incorporate Oral Fluency and Pragmatic Development?
}

\section{Lori G. Diepenbroek and Tracey M. Derwing}

We examined several popular integrated skills textbooks used in Language Instruction for Newcomers to Canada (LINC) and English as a second language (ESL) programs for pragmatics and oral fluency activities. Although many instructors use other resources to supplement classroom instruction, the textbook is still the backbone of many language courses. We wanted to know to what extent textbooks focus on pragmatics and oral fluency, as well as the range of activities featured in each. In light of the recent federal evaluation of LINC programs in Canada, which indicated extremely limited improvement in speaking and listening skills as a result of language instruction, it is important to know which textbooks offer the best opportunities for pragmatics and fluency development. We determined that very few textbook series are consistent in their inclusion of pragmatic content in terms of scope, quality, and quantity. As might be expected, oral fluency is not a major focus in integrated skills texts; however, those activities that are intended to enhance fluency development could easily be improved by an instructor.

Nous avons examiné plusieurs manuels intégrés que l'on emploie dans les programmes Cours de langue pour les immigrants au Canada (CLIC) et Anglais langue seconde (ALS) pour les activités portant sur la compétence pragmatique et la fluidité orale. Même si plusieurs enseignants ont recours à d'autres ressources pour compléter l'enseignement en classe, le manuel demeure la base de plusieurs cours de langue. Nous voulions déterminer dans quelle mesure les manuels portent sur la compétence pragmatique et la fluidité orale, et examiner la gamme d'activités qu'ils proposent. Compte tenu de l'évaluation des programmes CLIC récemment entreprise par le fédéral et qui a révélé que l'enseignement de la langue mène à une amélioration extrêmement limitée des aptitudes à parler et à écouter, il est important de savoir quels manuels offrent les meilleures possibilités pour le développement de la compétence pragmatique et la fluidité. Nous avons déterminé que très peu de séries de manuels offraient régulièrement un contenu pragmatique relativement à l'envergure, la qualité et la quantité. Comme on pouvait s'y attendre, les manuels intégrés ne mettent pas l'accent sur la fluidité orale; toutefois, les enseignants pourraient facilement améliorer les activités visant le développement de la fluidité orale. 
It may seem strange to examine general skills textbooks for oral fluency and pragmatics content; after all, it makes sense that oral/aural skills would be developed best through speaking and listening activities designed to meet second language (L2) students' specific needs. Nonetheless, there are several reasons that textbooks are sometimes the backbone of adult L2 programs, not the least of which are the demands on an instructor of a five-hour-per-day teaching schedule. The intensity of such programs precludes complete reliance on teacher-created materials. In addition, many Language Instruction for Newcomers to Canada (LINC) programs, as well as intensive English as a second language (ESL) programs, simultaneously hold several classes at the same proficiency levels. In order to standardize the content, a particular textbook may be chosen and used in each classroom, thus ensuring some degree of common ground when the students move on to the next proficiency level. Although textbooks should not be viewed as "the syllabus" for programs, they can provide a measure of continuity that may be lacking in a program without such a tangible learning resource.

Furthermore, new teachers often need direction for ideas of what to teach (especially if the program in which they work does not have an elaborated curriculum). They may also need some help in terms of how to introduce a given concept, and new teachers may benefit from assistance with regard to the sequencing of material. A textbook can be an invaluable resource in each of these instances (Masuhara, 2011). For all of these reasons, textbooks can take a prominent place in many language classrooms (Bragger \& Rice, 2000; Chapelle, 2009). Bragger and Rice note that textbooks are used "for curriculum design, for lesson planning, as a basis for assessment, and perhaps too often, to define their [instructors'] approach to teaching" (2000, p. 107). As Bell and Gower (2011) have pointed out, textbooks often offer a compromise for language classrooms that, although not necessarily optimal, may address the needs of multiple parties, including students, instructors, program directors, and publishers.

Although "speaking" and "listening" are traditional skill areas in language teaching, both descriptors cover a lot of ground, and, until the early 1990s, there was little differentiation of the many aspects that these two areas encompass. However, over the last 25 years, L2 researchers have begun to explore pragmatics, the "secret rules of language" (Yates, 2004, p. 3; see also Ishihara \& Cohen, 2010), oral fluency (Riggenbach, 1991), and pronunciation (Munro \& Derwing, 1995). We will not address the role that pronunciation plays in popular general skills texts here (see Derwing, Diepenbroek, \& Foote, 2012, for a discussion of pronunciation in ESL textbooks), but we will assess the listening and speaking aspects of pragmatics and fluency in 12 series of general skills ESL texts (see Appendix).

Recently, Citizenship and Immigration Canada (CIC, 2010) conducted an evaluation of LINC in which they assessed two comparable groups of ESL newcomers; one group registered for and took LINC classes, while the other 
group did not pursue any language instruction. As expected, the LINC group showed significantly more improvement in reading and writing in English than the comparison group, but, somewhat surprisingly, there was no difference between the instructed and uninstructed groups in terms of listening and speaking. In follow-up focus group interviews, former LINC students complained that there had been insufficient emphasis on speaking and listening in their classes. A multiyear longitudinal study of two groups of L2 learners (Mandarin and Slavic language speakers) also documented former LINC students' lack of opportunity to develop oral/aural skills in the classroom (Derwing \& Munro, 2013; Derwing, Munro, \& Thomson, 2008). These studies indicate that listening and speaking skills are underrepresented in many English language classrooms, which suggests that oral/aural aspects of pragmatics and fluency are also underrepresented. For these reasons, it is all the more important to gain a sense of what is available in popular ESL textbooks.

\section{Pragmatics}

Research indicates that pragmatic improvements can be made through instruction (Crandall \& Basturkmen, 2004; Rose, 2005; Takahashi, 2010). Findings also indicate that many pragmatic aspects of language, such as conversational implicature, are learned slowly and/or with great difficulty if not taught explicitly (Bouton, 1994). Both explicit and implicit instruction seem to foster the development of pragmatic competence (Koike \& Pearson, 2005; Rose, 2005). The opportunity to receive feedback also appears to facilitate pragmatic acquisition (Koike \& Pearson, 2005). Two types of pragmatic knowledge are involved in second language learning: sociopragmatic, that is, knowing when a speech act (or suitable utterance) is necessary; and pragmalinguistic, that is, knowing which semantic formula or speech act to use (Cohen, 2005; Jiang, 2006).

Given the importance of pragmatic instruction in the classroom, the relevance of the textbook to this instruction becomes key. A concern voiced in some research is the nature of the coverage that pragmatics receives in textbooks, in terms of both sequencing and quantity (Vellenga, 2004). Although there seems to be a widely accepted sequence for grammatical topics, there appears to be little research on the order in which pragmatic topics should be taught. The Canadian Language Benchmarks (CLB) Support Kit (Centre for Canadian Language Benchmarks, 2012) recently offered a framework for sequencing pragmatic topics. The article provides suggestions for appropriate topics at various proficiency levels, while acknowledging that the pragmatics issues taught should be based on the real-life needs of the learner. In Nguyen's (2011) survey of pragmatics material in an EFL textbook series, pragmatics topics such as advising and apologizing were not incorporated across all levels in the series, even though these are complex and challenging speech acts that may require additional attention. The speech act of "opening a conversa- 
tion" was practiced at all three levels of the series surveyed, while "closing a conversation" was not, even though it is questionable whether "opening a conversation" is more complex then closing one. Vellenga (2004) also surveyed pragmatic material in textbooks. She reported that pragmatic information generally consisted of only a phrase or two on a page. Vellenga also noted that "the distribution of speech act types across ESL and EFL textbooks did not appear to be patterned, nor based on frequency of speech act occurrence in natural language, and often seems counterintuitive" (2004, p. 9).

Another problem often identified with pragmatic materials in textbooks is their tendency to present speech acts in isolation. Speech acts can function as "islands of reliability" for learners, and they can both facilitate pragmatic ability and contribute to fluency by capitalizing on formulaic chunks (House, 1996), while other aspects of language such as grammar and vocabulary are still developing (Bardovi-Harlig \& Griffin, 2005). However, a focus on speech acts in isolation may be problematic for a number of reasons. First, an important component of pragmatic competence is the ability to account for contextual variables and to make linguistic choices while considering those variables. Previous research has demonstrated that pragmatic material is often presented in the absence of contextual information (Crandall \& Basturkmen, 2004; Nguyen, 2011; Vellenga, 2004; Washburn, 2001). Even if students master a particular speech act, they may not know in which contexts it would be appropriate (Cohen, 2005; Crandall \& Basturkmen, 2004; Vellenga, 2004). Furthermore, students may not be able to adapt the speech act to a specific situation. For example (as in Cohen \& Olshtain, 1993), a number of subtle adjustments may be made when apologizing. Rather than just saying "I'm sorry," one might say "I'm really sorry," offer an explanation or repair, accept responsibility, or mitigate the apology in some way. Moreover, the speech acts provided may be oversimplified (Crandall \& Basturkmen, 2004), and texts may actually misrepresent their suitability for a given situation (Koester, 2002). This appears, in part, to be an effort to make the materials as straightforward as possible for learners. Pragmatic competence often requires subtlety; an unfortunate consequence of the simplification of speech acts in textbooks may be that learners can actually be perceived as rude (Koester, 2002; Washburn, 2001).

Previous research indicates that textbooks are foundational in many classrooms, but the pragmatic topics incorporated in those textbooks are generally based on the writer's intuitions rather than corpus data or authentic language (Boxer \& Pickering, 1995; Jiang, 2006; Koester, 2002; Nguyen, 2011; Vasquez \& Sharpless, 2009; Vellenga, 2004). The contexts used to present speech acts and conversation strategies can be inauthentic. For instance, Boxer and Pickering (1995) found that even though complaints are most often used indirectly as a rapport-building device, most textbooks focus on their direct use. This is a particular concern because it puts the onus on the teacher to correct or supplement the pragmatic information provided; however, research also in- 
dicates that native speaker (NS) intuitions about pragmatics are not entirely trustworthy (Wolfson, 1989).

One final theme that runs through the literature is the need for learners to develop observation skills while developing pragmatic awareness. Because of the sheer volume of speech acts and conversation strategies, and the unlimited number of contextual variations, it is simply not possible for an instructor to teach everything the students need to know (Bardovi-Harlig, Hartford, Mahan-Taylor, Morgan, \& Reynolds, 1991). The classroom should therefore be a place where students can learn to make observations and develop awareness to equip them for encounters that have not been explicitly taught (Bardovi-Harlig \& Griffin, 2005; Koester, 2002).

\section{Fluency}

The term "fluency" either describes overall proficiency in a second language or, in the sense that we use here, refers to the smooth, automatic flow of speech (Gatbonton \& Segalowitz, 2005) and factors that can hamper this, such as pauses (both filled pauses with markers such as "um" and silent pauses), self-repetitions, and other hesitation devices. Studies such as Nation's (1989) have shown that oral fluency can be enhanced by classroom activities; furthermore, fluent speech will help L2 learners keep their listeners engaged (Rossiter, 2009), thus leading to more opportunities for interaction. Rossiter, Derwing, Manimtim, and Thomson (2010) undertook a review of 28 learner texts (including 14 general skills textbooks) and 14 teacher manuals to determine whether oral fluency activities were included, and if so, what types of activities were available. They found five types of activities designed to promote fluency in general skills textbooks: consciousness-raising tasks, rehearsal or repetition tasks, formulaic sequences, discourse markers, and free production activities; the latter was the most popular, appearing in 12 texts, followed by formulaic sequences and rehearsal, which appeared in 9 textbooks. Consciousness-raising activities and discourse markers were included in only 5 of the general texts. The authors concluded that the texts were unbalanced in terms of fluency-enhancing activities; for this reason they recommended that teachers supplement the texts with explicit oral fluency instruction. They provided examples of a wide range of activities to encourage fluency development in ESL classrooms.

In the current study, we address the following research questions:

1. To what extent are oral pragmatic activities represented in several popular student ESL textbooks?

2. To what extent are oral fluency activities represented in several popular student ESL textbooks?

3. What are the strengths and weaknesses of the pragmatic and fluency activities found in several popular student ESL textbooks? 


\section{Method}

We surveyed the pragmatic and fluency content from 12 integrated skills textbook series (48 individual texts) that ranged from beginner to advanced levels of proficiency (see Appendix). The most popular integrated skills texts were selected, as identified by major publishers in Canada (Oxford University Press, Pearson Education, Longman, Pearson Longman, and Cambridge University Press). Although other major publishers were contacted (e.g., Nelson, Prentice Hall, and McGraw Hill), their best sellers focus on individual or pairs of skills (listening and speaking, reading and writing, etc.). To maintain consistency, we did not include such books.

\section{Pragmatics}

Pragmatic content, for our purposes, included three main features. The first was speech acts, because we anticipated that most language courses would rely heavily on their use (Koester, 2002). They allow pragmatic content to be incorporated in a formulaic way, which therefore would likely appeal to textbook writers. Speech acts are also the most researched aspect of pragmatics (Kasper, 2006). The second main feature focused on wider and less formulaic pragmatic topics involving conversation strategies, such as interpreting conversation cues and illocutionary force. The third main category was idioms. Although they do not strictly fall in the realm of pragmatics, idioms qualify as "hidden rules of language" in that they are opaque to language learners.

An initial list of speech acts and conversation strategies was created for coding purposes, and additional topics were added as they were encountered in the texts. As a result, the coding list was not exhaustive, but it represented each of the speech acts or conversation strategies present in the analyzed texts. Most textbooks did not clearly define speech acts or conversation strategies, so they were coded as they were named in the text. The line between advice and suggestions was not always clear, even within a given text. For example, in Interchange 2 (Richards, 2005, p. 47), learners study how to make suggestions, but when they review the concept later (p. 56), the topic is labelled as advice. The former was entered as "suggestions" in our spreadsheet and the latter as "advice," even though the language and intent were similar and, in fact, in some instances indistinguishable from each other.

At the outset, conversation strategies were entered as a single category in an effort to simplify the reporting. There were so many, however, that we reclassified the strategies into subcategories, including conversation management, illocutionary force, interpreting conversation cues, indirect questions, explaining/paraphrasing, negative questions, question tags, small talk, and social expressions (see Table 1). 
Table 1

Categories and Examples or Explanations of Conversation Strategies

\begin{tabular}{|c|c|}
\hline Coding category & Example(s) or explanation \\
\hline Conversation management & $\begin{array}{l}\text { Initiating/maintaining/closing conversations, turn taking, } \\
\text { rapport building, changing the topic, showing understand- } \\
\text { ing, interrupting }\end{array}$ \\
\hline Illocutionary force & $\begin{array}{l}\text { Making an utterance stronger or softer - extent of directness } \\
\text { (really, just) }\end{array}$ \\
\hline Interpreting conversation cues & Emotions; relationships between speakers \\
\hline Indirect questions & I wonder if.... \\
\hline \multicolumn{2}{|l|}{ Explaining/paraphrasing } \\
\hline Negative questions & You don't like it? \\
\hline Question tags & When there was a pragmatic focus \\
\hline Small talk & How to do it; appropriate topics \\
\hline Social expressions & Congratulations! Way to go! \\
\hline
\end{tabular}

Although many texts included information about, for example, gestures and general cultural norms, we did not include topics that did not require the use of verbal language. Activities with general cultural information, such as "If you want to visit someone at home, you are supposed to call first" (Interchange 3, Richards, 2005, p. 33), were not included. Activities in which a speech act or conversation strategy was introduced incidentally but was not a focus of the activity were not included.

\section{Fluency}

Fluency activities were coded according to the type of task. For this study, we examined activities that would enhance the flow of speech, such as formulaic speech, role-plays, repetition, and preplanning. We made a distinction between tasks that focused on accuracy and tasks that focused on fluency, and therefore had to make many judgment calls about the nature of the tasks. Our rationale was that if students were focused on the accuracy of an utterance, it would be difficult to attend to fluency and the flow of language would be compromised. As well, if students could read the required language from the book, we did not include the task. This was frequently the case with roleplays and other activities.

Pragmatic and fluency activities were identified by examining each textbook, page by page, and recording any relevant activities. The first time through, we identified pragmatic activities. The second time through, fluency activities were recorded on a separate spreadsheet. Each time, the page number and chapter, number of lines, general topic/activity, and a brief description of each activity were recorded on a spreadsheet.

If a textbook had a relevant pragmatic topic with more than one related activity or exercise, each activity was entered separately. For example, in 
American Headway 3 (Soars \& Soars, 2003), the topic of indirect speech is introduced. In the first activity, students are asked to fill in blanks to create phrases used for speaking indirectly (e.g., "I wonder if you could help $\left.m e^{\prime \prime}\right)$. In the second activity, students use prompts to ask questions, and in the third activity they are expected to ask and answer, in pairs, questions based on the ideas in the previous activity. We therefore coded this section as three separate entries. When activities mentioned more than one distinct speech act or pragmatic topic, two topics were assigned to a single entry (for example, inviting and offering), although this happened only rarely. Some activities that contained a speech act along with a secondary pragmatic topic (such as "making polite requests") were entered only as "requests."

In some fluency entries, more than one type of task appeared (for example, a role-play using formulaic language). In these cases we entered only one code because there was often overlap in these types of tasks, and the reporting of the number of tasks would be severely inflated. In such cases, the researchers used their judgment about which task type was the primary focus.

After the initial entries were recorded, the spreadsheets were checked by another researcher for accuracy. The total number of entries, the frequency of each topic, and the number of units and pages on which pragmatic and fluency content was found were tallied using a computer program and then checked again manually.

\section{Results}

\section{Pragmatics}

When we examined the frequency of the coding categories across all textbooks, we found that conversation strategies, requests, and advice all occurred more than 100 times (see Table 2). Formality, politeness, compliments, and thanking, on the other hand, appeared fewer than 20 times each.

Table 3 shows the breakdown of conversation strategies by type. Conversation management (e.g., turn-taking, opening and closing, showing interest) was represented far more often than any other category. Small talk, social expressions, and interpreting conversational cues appeared in most of the texts, but at relatively low rates. No textbook covered all of the categories, and some texts offered nothing in several of the conversation strategy categories.

When we examined pragmatic activities by textbooks, we simply totalled the number in each book. The course books containing the most pragmatic content (over 75 instances) included Workplace Plus 3 (Saslow, 2002), Workplace Plus 2 (Saslow, 2002), and all the texts in the Touchstone series (McCarthy, MacCarten, \& Sandiford, 2005, 2006). Those texts with only 10 
or fewer pragmatic activities according to our scoring system included Side by Side 3 (Molinsky \& Bliss (2002), Ventures Basic (Bitterlin, Johnson, Price, Ramirez, \& Savage, 2008), Ventures 1 (Bitterline et al., 2008), and Canadian Concepts 1, 2, 3, 5, and 6 (Berish \& Thibaudeau, 1997). Table 4 indicates the relative frequency of pragmatic activities in individual texts.

Table 2.

Frequency of Pragmatic Categories Across All Texts

\begin{tabular}{lrlr}
\hline Pragmatic Codes & & & \\
\hline Conversation strategies & 443 & Apologizing & 44 \\
Requests & 225 & Clarifying & 42 \\
Advice & 165 & Inviting & 42 \\
Introductions & 94 & Complaining & 42 \\
Greeting & 83 & Prohibition & 35 \\
Suggesting & 79 & Recommending & 30 \\
Obligation & 78 & Sympathizing & 24 \\
Offering & 73 & Refusing & 23 \\
Opinions & 57 & Formality & 16 \\
Excuses & 54 & Politeness & 13 \\
Agreeing & 50 & Compliment & 11 \\
Other speech act & 47 & Thanking & 9 \\
\hline
\end{tabular}

Table 3.

Conversation Strategy Counts

\begin{tabular}{lr}
\hline Topic & Count \\
Conversation management & 249 \\
Small talk, appropriate topics & 42 \\
Interpreting conversational cues & 39 \\
Social expressions & 39 \\
Indirect Questions & 23 \\
Illocutionary force & 21 \\
Question tags & 11 \\
Explaining/paraphrasing & 11 \\
Negative questions & 8 \\
Total & 443
\end{tabular}


Table 4

Frequency of Pragmatic Occurrences in Individual Texts

\begin{tabular}{lrlr}
\hline Text & Freq. & Text & Freq. \\
\hline Workplace Plus 3 & 112 & Ventures 4 & 26 \\
Touchstone 2 & 103 & Side by Side 1 & 25 \\
Workplace Plus 2 & 92 & Worldview 3 & 25 \\
Touchstone 3 & 83 & Interchange Intro & 24 \\
Touchstone 4 & 77 & Passages 2 & 24 \\
Touchstone 1 & 76 & Amer. English File 2 & 21 \\
Interchange 2 & 70 & Ventures 2 & 21 \\
Interchange 3 & 67 & Amer. Eng. File 4 & 19 \\
American Head. 3 & 62 & Worldview 4 & 18 \\
Step Forward Can. 2 & 62 & Side by Side 2 & 16 \\
Workplace Plus 4 & 62 & Ventures 3 & 16 \\
American Head. 4 & 56 & American Headway 1 & 14 \\
Top Notch Fund. & 55 & Canadian Concepts 4 & 14 \\
Workplace Plus 1 & 55 & Step Forward Can. 1 & 14 \\
Worldview 2 & 51 & Amer. English File 1 & 13 \\
Passages 1 & 46 & Side by Side 4 & 12 \\
Interchange 1 & 45 & Canadian Concepts 2 & 10 \\
Top Notch 2 & 42 & Side by Side 3 & 10 \\
Worldview 1 & 40 & Canadian Concepts 1 & 9 \\
American Headway 2 & 39 & Ventures 1 & 8 \\
American Head. Start. & 36 & Canadian Concepts 3 & 6 \\
Top Notch 3 & 36 & Canadian Concepts 6 & 5 \\
Amer. English File 3 & 31 & Canadian Concepts 5 & 2 \\
Top Notch 1 & 29 & Ventures Basic & 0 \\
\hline
\end{tabular}

Table 5 shows the average number of pragmatic activities across each series, according to our scoring system. Touchstone (McCarthy et al., 2005, 2006) had the highest incidence, with a mean of 84.8 activities per volume, while the series with the lowest number, Canadian Concepts (Berish \& Thibaudeau, 1997), had only 7.7. We see considerable inconsistency both within and across series. There appears to be no discernable pattern in some series, and there is no consensus on when to introduce or develop pragmatic content.

\section{Fluency}

We first recorded the frequency of fluency activities in individual texts (see Table 6). When we examined the types of fluency activities across all texts, we found that formulaic language was best represented (119 instances; see Table 7), followed by role-play (104; see Table 8), repetition (39; see Table 9), and preplanning (8; see Table 10). 
Table 5

Textbooks' Number of Pragmatic Activities with Series Means

\begin{tabular}{|c|c|c|c|c|c|}
\hline Text & \# & $M$ & Text & \# & $M$ \\
\hline American English File 1 & 13 & & Step Forward Canada 1 & 14 & \\
\hline American English File 2 & 21 & & Step Forward Canada 2 & 62 & 38 \\
\hline American English File 3 & 31 & & & & \\
\hline \multirow[t]{2}{*}{ American English File 4} & 19 & 21 & Top Notch 1 & 29 & \\
\hline & & & Top Notch 2 & 42 & \\
\hline American Headway 1 & 14 & & Top Notch 3 & 36 & \\
\hline American Headway 2 & 39 & & Top Notch Fundamentals & 55 & 40.5 \\
\hline American Headway 3 & 62 & & & & \\
\hline American Headway 4 & 56 & & Touchstone 1 & 76 & \\
\hline \multirow[t]{2}{*}{ Amer. Headway Starter } & 36 & 41.1 & Touchstone 2 & 103 & \\
\hline & & & Touchstone 3 & 83 & \\
\hline Canadian Concepts 1 & 9 & & Touchstone 4 & 77 & 84.8 \\
\hline Canadian Concepts 2 & 10 & & & & \\
\hline Canadian Concepts 3 & 6 & & Ventures 1 & 8 & \\
\hline Canadian Concepts 4 & 14 & & Ventures 2 & 21 & \\
\hline Canadian Concepts 5 & 2 & & Ventures 3 & 16 & \\
\hline \multirow[t]{2}{*}{ Canadian Concepts 6} & 5 & 7.7 & Ventures 4 & 26 & \\
\hline & & & Ventures Basic & 0 & 14.2 \\
\hline Interchange 1 & 45 & & & & \\
\hline Interchange 2 & 70 & & Workplace Plus 1 & 55 & \\
\hline Interchange 3 & 67 & & Workplace Plus 2 & 92 & \\
\hline \multirow[t]{2}{*}{ Interchange Intro } & 24 & 51.5 & Workplace Plus 3 & 112 & \\
\hline & & & Workplace Plus 4 & 62 & 80.3 \\
\hline Passages 1 & 46 & & & & \\
\hline \multirow[t]{2}{*}{ Passages 2} & 24 & 35 & Worldview 1 & 40 & \\
\hline & & & Worldview 2 & 51 & \\
\hline Side by Side 1 & 25 & & Worldview 3 & 25 & \\
\hline Side by Side 2 & 16 & & Worldview 4 & 18 & 33.5 \\
\hline Side by Side 3 & 10 & & & & \\
\hline Side by Side 4 & 12 & 15.8 & & & \\
\hline
\end{tabular}

Table 6

Frequency of Fluency Activities in Individual Texts

\begin{tabular}{lrlrlr}
\hline Text & Freq. & Text & Freq. & Text & Freq. \\
\hline Interchange 3 & 33 & Amer. Headway Starter & 14 & Amer. Headway 1 & 6 \\
Interchange Intro & 28 & American English File 2 & 13 & Top Notch 2 & 6 \\
Interchange 1 & 22 & Step Forward Canada 2 & 13 & Worldview 4 & 6 \\
Touchstone 1 & 22 & Worldview 3 & 12 & Workplace Plus 1 & 5 \\
Interchange 2 & 21 & American English File 4 & 10 & Workplace Plus 2 & 5 \\
Touchstone 4 & 21 & Canadian Concepts 2 & 10 & Side by Side 1 & 4 \\
Worldview 1 & 20 & Top Notch 3 & 10 & Ventures Basic & 4 \\
Touchstone 2 & 19 & Canadian Concepts 1 & 9 & Side by Side 4 & 3 \\
Top Notch 1 & 17 & Passages 1 & 9 & Can. Concepts 3 & 2 \\
Top Notch Fund. & 17 & Ventures 1 & 9 & Can. Concepts 4 & 2 \\
Worldview 2 & 17 & American Headway 4 & 8 & Side by Side 2 & 2 \\
Amer. English File 3 & 16 & Workplace Plus 3 & 8 & Ventures 2 & 2 \\
Touchstone 3 & 16 & American English File 1 & 7 & Side by Side 3 & 1 \\
Step V Can. 1 & 15 & Ventures 3 & 7 & Can. Concepts 5 & 0 \\
Amer. Headway 2 & 14 & Ventures 4 & 7 & Can. Concepts 6 & 0 \\
Amer. Headway 3 & 14 & Workplace Plus 4 & 7 & Passages 2 & 0 \\
\hline
\end{tabular}


Table 7

Frequency of Formulaic Activities in Individual Texts

Text

- Interchange 3

Freq.

- Interchange Intro

- Touchstone 4

- American Headway Starter, Touchstone 2

- Interchange 2

- Touchstone 1

- Interchange 1

- Top Notch Fundamentals

- Touchstone $3 \quad 6$

- American English File 4, Ventures 1, Workplace Plus 3

- American Headway 2, American Headway 4, Step Forward Canada 1, 4 Top Notch 1, Worldview 1

- Amer. English File 2, American Headway 1, Ventures 3, Workplace Plus 1

- American English File 3, American Headway 3, Canadian Concepts 2, Side by 2 Side 4, Top Notch 3, Ventures 4, Ventures Basic, Workplace Plus 2

- Amer. English File 1, Can. Concepts 1, Can. Concepts 3, Passages 1, Side by 1 Side 2, Step Forward Can. 2, Ventures 2, Workplace Plus 4, Worldview 2

- Can. Concepts 4, Can. Concepts 5, Can. Concepts 6, Passages 2, Side by 0 Side 1, Side by Side 3, Top Notch 2, Worldview 3, Worldview 4

Table 8

Frequency of Role-Play Activities in Individual Texts

Text

Freq.

- Interchange 1

- Worldview 1, Worldview 2

- Step Forward Canada 2, Worldview $3 \quad 12$

- Top Notch 1

- American Headway 3, Interchange 2, Interchange $3 \quad 10$

- American Headway 2, Touchstone $3 \quad 9$

- American English File 2, American English File $3 \quad 8$

- Touchstone 2, Touchstone 4

- Passages 1, Step Forward Canada 1, Top Notch 3, Workplace Plus 4

- Top Notch 2

- American Headway 4, Touchstone 1

- American English File 4, American Headway 1, American Headway Starter,
Interchange Intro, Ventures 4, Workplace Plus 3

- Side by Side 1, Worldview 4

- Can. Concepts 2, Can. Concepts 3, Side by Side 2, Side by Side 4, Top Notch Fundamentals, Ventures 3, Workplace Plus 1, Workplace Plus 2

- Amer. English File 1, Can. Concepts 1, Can. Concepts 4, Can. Concepts 5, Can. Concepts 6, Passages 2, Side by Side 3, Ventures 1, Ventures 2, Ventures Basic 
Table 9.

Frequency of Repetition Activities in Individual Texts

Text Freq.

- Top Notch Fundamentals

- Canadian Concepts 1, Interchange Intro, Touchstone 1 9

- Canadian Concepts 2

- American English File 1, Step Forward Canada 1

- Ventures 1

- Ventures 3

- American English File 3, Passages 1, Side by Side 1, Ventures 4, Ventures Basic, Workplace Plus 2, Worldview 1

- Amer. English File 2, Amer. Headway 3, Interchange 1, Side by Side 3, Top Notch 1, Top Notch 2, Top Notch 3, Ventures 2, Workplace Plus 1, Worldview 2

- Amer. English File 4, Amer. Headway 1, Amer. Headway 2, Amer. Headway 4, Amer. Headway Starter, Can. Concepts 3, Can. Concepts 4, Can. Concepts 5, Can. Concepts 6, Interchange 2, Interchange 3, Passages 2, Side by Side 2, Side by Side 4, Step Forward Canada 2, Touchstone 2, Touchstone 3, Touchstone 4, Workplace Plus 3, Workplace Plus 4, Worldview 3, Worldview 4

Table 10.

Frequency of Preplanning Activities in Individual Texts

Text

Freq.

- American English File 3, Worldview 4

- American English File 4, Canadian Concepts 4, Worldview 2

- American English File 1, American English File 2, American Headway 2, American Headway 3, Interchange 2, Top Notch 1, Top Notch 3, Touchstone 1, Touchstone 2, Touchstone 3, Touchstone 4, Worldview 1

- Amer. Headway 1, Amer. Headway 4, Amer. Headway Starter, Can. Concepts 1, Can. Concepts 2, Can. Concepts 3, Can. Concepts 5, Can. Concepts 6, Interchange 1, Interchange 3, Interchange Intro, Passages 1, Passages 2, Side by Side 1, Side by Side 2, Side by Side 3, Side by Side 4, Step Forward Canada 1, Step Forward Canada 2, Top Notch 2, Top Notch Fundamentals, Ventures 1, Ventures 2, Ventures 3, Ventures 4, Ventures Basic, Workplace Plus 1, Workplace Plus 2, Workplace Plus 3, Workplace Plus 4, Worldview 3

Twenty-five of the texts have fewer than 10 true oral fluency activities according to the rubric we used, while only seven texts have 20 or more. To give a sense of how limited some of the texts are, nine textbooks had only one oral fluency activity involving formulaic speech, and another nine had none. Preplanning was the least represented fluency activity of all. Two books had four instances of preplanning activities, three books had two each, and all the rest had one or no preplanning activities. The other main finding with regard to fluency activities is the tendency for some textbooks to focus on a single task type rather than to incorporate all of the four types systematically. 


\section{Discussion}

Before we discuss the pragmatics and fluency findings, we want to reiterate that our protocol for coding was arbitrary, as are all such protocols; however, coding was consistent across all texts. In the case of pragmatics, we generally had little difficulty coding once we had developed the categories. Sometimes textbooks would offer an activity that might be considered pragmatic, but if there was no explicit explanation or opportunity to practice, then it was not included. Some activities offered more than one pragmatic topic-for example, "inviting" and "refusing." In such cases, we counted both, so the total numbers occasionally may be higher than the actual number of activities.

The coding of fluency activities, on the other hand, was less straightforward. Our impression was that textbook writers clearly intended to include pragmatic, grammatical, and lexical content, but oral fluency was less deliberately included. This may simply be because it is assumed that teachers will incorporate oral fluency in other ways, rather than relying on a written textbook. It could be argued that almost any of the material in the ESL texts is fluency-building (e.g., vocabulary is necessary for good oral skills); however, we were looking for targeted fluency exercises. Thus, a given activity may have had some fluency content, but if the emphasis was primarily on grammatical accuracy, we did not include it. We also chose to ignore activities that may have otherwise been considered "fluency builders" if the students had everything necessary to read directly from the textbook rather than relying on their own words.

\section{Pragmatics}

Research questions 1 and 3 dealt with pragmatics. To address research question 1 -the extent to which oral pragmatic activities are represented in popular student ESL textbooks - we first defined and categorized pragmatic activities, established a protocol for coding, and examined the 48 textbooks for instances of these activities. The most notable finding here was the lack of consistency in coverage of pragmatics in some textbooks. Although a few series included a wide range of speech acts and conversation strategies, many more had rather inconsistent treatment. Within the same series, we found 62 instances in Workplace Plus 4 (Saslow, 2003), a little more than half as many pragmatic activities as in Workplace Plus 3 (Saslow, 2002), which has 112, despite the fact that the students' proficiency at Workplace Plus 4 should allow them to handle additional pragmatic topics. Similarly, Canadian Concepts 4 (Berish \& Thibaudeau, 1997) has 14 instances of coded pragmatic activities, while Canadian Concepts 5 (Berish \& Thibaudeau, 1997) has only 2.

Research question 3 concerned the strengths and weaknesses of the textbooks examined. An examination of the texts across each series showed no 
clear rationale for choosing which speech acts and conversation strategies to include. Worldview 1-4 (Rost, le Maistre, Lewis, \& Sharpe, 2005) offers "requests" across the whole series, but there are many gaps in which no given speech act is featured. In the Interchange series (Richards, 2005), "advice" and "requests" are included several times in every text, but other speech acts occurred not at all or very rarely. It was difficult to identify a systematic approach to pragmatics in most of the texts, with the notable exception of Touchstone (McCarthy et al., 2005, 2006), which consistently focused on conversation strategies throughout the series.

We were also concerned with quality and depth of coverage. Consider, for instance, Workplace Plus 3 (Saslow, 2002), which our examination showed as having the greatest number of pragmatic activities. However, the book's format of "listen and read," "listen and repeat," followed by a highly structured pair work activity, all on the same pragmatic form (e.g., Express frustration with an equipment malfunction. Empathize [p. 32]), led to an inflated representation because the activities were superficial with little or no explanation and practically no variation in design. In the example given, students may have trouble transferring the ability to express frustration to another context, situation, or register. Given that speech acts vary according to the participants' relationships and the degree of imposition, it is important that texts offer some explanation of which speech acts are appropriate, when they are appropriate, and for whom they are appropriate. In many texts, however, a list of speech acts was offered, but with no information on variations necessary for different circumstances. For example, in Side by Side 3, "Asking for a Favor" (Molinsky \& Bliss, 2002, p. 29), four versions of a request are provided: Could you do me a favor? Could you possibly do me a favor? Could you do a favor for me? Could I ask you a favor? No information is given as to the differences among these forms or when and why a person might choose one over another. The only instruction is to "Practice the conversations in this lesson again. Ask for a favor in different ways." The students may be able to ask for a favour using these phrases, but they will not know which is most appropriate for a given context. There is an assumption that the teacher will be able to explain the differences, but teacher intuitions are not always reliable (Tatsuki \& Houck, 2010). Furthermore, there is no indication that one can ask another person for a favour without actually using the word "favour," as in "I was wondering if you could help me out."

Another major problem identified in this survey was the lack of contextualization. Students were rarely offered information about interlocutors' relationships, register, or other factors that contribute to variation in pragmatic choices. The approach to teaching pragmatics appears to be based on similar approaches to teaching grammar, rather than taking into consideration the necessary contextualization of speech acts and conversation strategies. A few texts included good exemplars, such as Touchstone 3 (McCarthy et al., 2006, p. 49), which offered a clear context for polite refusal in which the students were 
assigned a role as a guest at a party. A picture provided information on the situation and the ages of the speakers, and students were also given useful phrases for refusing offers of food and drink.

A few series offered opportunities for students to make observations (as recommended by Bardovi-Harlig et al., 1991). American Headway 3 (Soars \& Soars, 2003), for instance, presented a script (p. 4) and a CD of a father and daughter conversation in which the daughter responded to questions from her father with one-word answers. The students were asked to focus on the context, and to consider the tone that a conversation can have. They read what was a relatively abrupt and rude set of responses, and then heard a similar conversation in which the daughter gave more elaborated answers. The students could then compare the two directly and see the affective difference. Similar activities, such as listening to determine whether the interlocutors know each other, and on what basis the students could identify the relationship, help students to focus on pragmatic aspects of conversations in English. Because there is such a wide range of speech acts, teaching these observations is key -it is not possible to cover every conceivable context, but it is possible to encourage students to listen actively and to identify differences dependent on the pragmatics of a given situation.

Another feature we were looking for was the use of corpus data to inform the activities and topics in the textbooks. One series that stood out above the rest in this regard was Touchstone (McCarthy et al., 2005, 2006), which is corpus-based and provided more consistent coverage on pragmatic themes than any other series. Corpus data can be extremely useful, in that they can provide textbook writers and teachers with an indication of the most frequently used expressions, thus offering a rubric for prioritization.

\section{Fluency}

Research questions 2 and 3 dealt with fluency. We asked to what extent oral fluency activities are represented in popular student ESL textbooks. When we examined the total number of fluency activities across all texts, we found a preference for role-plays and formulaic speech, whereas repetition and preplanning were much less evident. Preplanning has been shown to be an important strategy for fluency development (Foster \& Skehan, 1996, 1999), yet it has been ignored in the majority of the texts that we surveyed here. The quality of fluency activities in general was somewhat lacking. Furthermore, there was considerable variation across texts, many having few oral fluency activities, especially ones that pushed the students to speak on their own, without relying on reading. Generally speaking, these integrated textbooks were not very useful for the development of oral fluency, which may have contributed to CIC's (2010) finding that LINC students do not make any more progress in speaking and listening than newcomers who do not take language classes. 


\section{Recommendations for Teachers}

In noting the inconsistencies of pragmatic data across the textbooks we examined, we recommend that program directors and teachers seek out textbooks based on corpus data, to ensure a more authentic representation of frequency of speech acts. We also suggest that teachers point out contextual variables for students whenever doing pragmatic activities, so that students are aware of appropriate speech for a range of interlocutors, taking into consideration such things as the degree of imposition involved. Students should be helped to understand the differences between options for a given speech act.

If using fluency activities from a textbook, we suggest that instructors ensure the students are not able to read the answers; they should close their textbooks before completing the task. Students can be asked to rotate through multiple partners to include both repetition and formulaic speech in their classroom routines (see Nation, 1989). Students should also be given time for preplanning to enhance their oral fluency skills. Finally, given the limited gains that LINC students make in oral fluency, it is likely preferable to rely on other approaches to fluency development (see Rossiter et al., 2010), rather than to teach fluency through the use of a textbook.

\section{Acknowledgements}

We are grateful to Andrea Kushnir, Jun Deng, Jennifer Foote, and Sarvenaz Hatami for their assistance with this project. We also thank Cambridge, Oxford, and Pearson Longman publishers, who donated some of the texts reviewed here. Two anonymous reviewers made helpful suggestions. This work was supported by the Social Sciences and Humanities Research Council of Canada (SRG 410-2010-0151); a Support for the Advancement of Scholarship grant, Faculty of Education, University of Alberta; a grant from the Office of the Vice-President, Research, University of Alberta; and a grant from the Faculty of Education, University of Alberta, all awarded to the second author.

\section{The Authors}

Lori Diepenbroek has a Master's in TESL from the University of Alberta. She currently teaches pragmatics in a bridging program for immigrants from health professions.

Tracey Derwing is a professor in TESL at the University of Alberta. Her research interests include the oral language skills of immigrants as well as settlement issues.

\section{References}

Bardovi-Harlig, K., \& Griffin, R. (2005). L2 pragmatic awareness: Evidence from the ESL classroom. System, 33(3), 401-415.

Bardovi-Harlig, K., Hartford, B. A. S., Mahan-Taylor, R., Morgan, M. J., \& Reynolds, D. W. (1991). Developing pragmatic awareness: Closing the conversation. ELT Journal, 45(1), 4-15.

Bell, J., \& Gower, R. (2011). Writing course materials for the world: A great compromise. In B. Tomlinson (Ed.), Materials development in language teaching (pp. 135-150). Cambridge, UK: Cambridge University Press.

Bouton, L. F. (1994). Conversational implicature in a second language: Learned slowly when not deliberately taught. Journal of Pragmatics, 22(2), 157-167. 
Boxer, D., \& Pickering, L. (1995). Problems in the presentation of speech acts in ELT materials: The case of complaints. ELT Journal, 49(1), 44-58.

Bragger, J. D., \& Rice, D. B. (2000). Foreign language materials: Yesterday, today, and tomorrow. In R. M. Terry (Ed.), Agents of change in a changing age (pp. 107-140). Lincolnwood, IL: National Textbook Company.

Centre for Canadian Language Benchmarks (CCLB). (2012). CLB support kit. Ottawa, ON: Author. Retrieved from http://www.language.ca/index.cfm?Voir=sections\&Id=17356\&M=4038\&Rep ertoire_No=2137991327

Chapelle, C. A. (2009). A hidden curriculum in language textbooks: Are beginning learners of French at U.S. universities taught about Canada? Modern Language Journal, 93(2), 139-152.

Citizenship and Immigration Canada (CIC). (2010). Evaluation of the Language Instruction for Newcomers to Canada (LINC) program. Ottawa, ON: Evaluation Division, CIC. Retrieved from http://www.cic.gc.ca/ENGLISH/resources/evaluation/linc/2010/linc-eval.pdf

Cohen, A. D. (2005). Strategies for learning and performing L2 speech acts. Intercultural Pragmatics, 2(3), 275-301.

Cohen, A. D., \& Olshtain, E. (1993). The production of speech acts by EFL learners. TESOL Quarterly, 27(1), 33-56.

Crandall, E., \& Basturkmen, H. (2004). Evaluating pragmatics-focused materials. ELT Journal, $58(1), 38-49$.

Derwing, T. M., Diepenbroek, L. G., \& Foote, J. A. (2012). How well do general-skills ESL textbooks address pronunciation? TESL Canada Journal, 30(1), 22-44.

Derwing, T. M., \& Munro, M. J. (2013). The development of L2 oral language skills in two L1 groups: A 7-year study. Language Learning, 63(2), 163-185.

Derwing, T. M., Munro, M. J., \& Thomson, R. I. (2008). A longitudinal study of ESL learners' fluency and comprehensibility development. Applied Linguistics, 29(3), 359-380.

Foster, P., \& Skehan, P. (1996). The influence of planning and task type on second language performance. Studies in Second Language Acquisition, 18(3), 299-323.

Foster, P., \& Skehan, P. (1999). The influence of source of planning and focus of planning on task-based performance. Language Teaching Research, 3(3), 215-247.

Gatbonton, E., \& Segalowitz, N. (2005). Rethinking communicative language teaching: A focus on access to fluency. Canadian Modern Language Review, 61(3), 325-353.

House, J. (1996). Developing pragmatic fluency in English as a foreign language. Studies in Second Language Acquisition, 18(1), 225-252.

Ishihara, N., \& Cohen, A. D. (2010). Teaching and learning pragmatics: Where language and culture meet. Harlow, UK: Pearson Education.

Jiang, X. (2006). Suggestions: What should ESL students know? System, 34(1), 36-54.

Kasper, G. (2006). Speech acts in interaction: Towards discursive pragmatics. In K. BardoviHarlig, C. Felix-Brasdefer, \& A. S. Omar (Eds.), Pragmatics and language learning (pp. 281-314). Honolulu, HI: University of Hawai'i Press.

Koester, A. J. (2002). The performance of speech acts in workplace conversations and the teaching of communicative functions. System, 30(2), 167-184.

Koike, D. A., \& Pearson, L. (2005). The effect of instruction and feedback in the development of pragmatic competence. System, 33(3), 481-501.

Masuhara, H. (2011). What do teachers really want from coursebooks? In B. Tomlinson (Ed.), Materials development in language teaching (pp. 236-266). Cambridge, UK: Cambridge University Press.

Munro, M. J., \& Derwing, T. M. (1995). Foreign accent, comprehensibility, and intelligibility in the speech of second language learners. Language Learning, 45(1), 73-97.

Nation, I. S. P. (1989). Improving speaking fluency. System, 17(3), 377-384.

Nguyen, M. T. T. (2011). Learning to communicate in a globalized world: To what extent do school textbooks facilitate the development of intercultural pragmatic competence? RELC Journal, 42(1), 17-30. 
Riggenbach, H. (1991). Toward an understanding of fluency: A microanalysis of nonnative speaker conversations. Discourse Processes, 14(4), 423-441.

Rose, K. R. (2005). On the effects of instruction in second language pragmatics. System, 33(3), 385-399.

Rossiter, M. J. (2009). Perceptions of L2 fluency by native and non-native speakers of English. Canadian Modern Language Review, 65(3), 395-412.

Rossiter, M. J., Derwing, T. M., Manimtim, L. G., \& Thomson, R. I. (2010). Oral fluency: The neglected component in the communicative language classroom. Canadian Modern Language Review, 66(4), 583-606.

Takahashi, S. (2010). The effect of pragmatic instruction on speech act performance. In A. Martinez-Flor \& E. Uso-Juan (Eds.), Speech act performance: Theoretical, empirical and methodological issues (pp. 127-142). Philadelphia, PA: John Benjamins.

Tatsuki, D. H., \& Houck, N. R. (Eds.). (2010). Pragmatics: Teaching speech acts. Alexandria, VA: TESOL.

Vasquez, C., \& Sharpless, D. (2009). The role of pragmatics in the Master's TESOL curriculum: Findings from a nationwide survey. TESOL Quarterly, 43(1), 5-28.

Vellenga, H. (2004). Learning pragmatics from ESL \& EFL textbooks: How likely? TESL-EJ, 8(2). Retrieved from http://tesl-ej.org/ej30/a3.html

Washburn, G. N. (2001). Using situation comedies for pragmatic language teaching and learning. TESOL Journal, 10(4), 21-26.

Wolfson, N. (1989). Perspectives: Sociolinguistics and TESOL. Cambridge, MA: Newbury House.

Yates, L. (2004). The "secret rules of language": Tackling pragmatics in the classroom. Prospect, 19(1), 3-21.

\section{Appendix: Textbooks Surveyed}

Berish, L., \& Thibaudeau, S. (1997). Canadian concepts 1, 2, 3, 4, 5, \& 6 (2nd ed.). Don Mills, ON: Pearson Education.

Bitterlin, G., Johnson, D., Price, D., Ramirez, S., \& Savage, K. L. (2008). Ventures basic, 1, 2, 3, \& 4. White Plains, NY: Cambridge University Press.

McCarthy, M., MacCarten, J., \& Sandiford, H. (2005). Touchstone 1 \& 2. Cambridge, UK: Cambridge University Press.

McCarthy, M., MacCarten, J., \& Sandiford, H. (2006). Touchstone 3 \& 4. Cambridge, UK: Cambridge University Press.

Molinsky, S. J., \& Bliss, B. (2001). Side by side 1 \& 2 (3rd ed.). White Plains, NY: Pearson Longman.

Molinsky, S. J., \& Bliss, B. (2002). Side by side 3 (3rd ed.). White Plains, NY: Pearson Longman.

Molinsky, S. J., \& Bliss, B. (2003). Side by side 4 (3rd ed.). White Plains, NY: Pearson Longman.

Oxenden, C., Latham-Koenig, C., \& Seligson, P. (2008). American English file 1 \& 2. New York, NY: Oxford University Press.

Oxenden, C., Latham-Koenig, C., \& Seligson, P. (2009). American English file 3 \& 4. New York, NY: Oxford University Press.

Rajabi, S., \& Spigarelli, J. (2008). Step forward Canada 1. Don Mills, ON: Oxford University Press.

Rajabi, S., \& Wisniewska, I. (2008). Step forward Canada 2. Don Mills, ON: Oxford University Press.

Richards, J. C. (2005). Interchange intro, 1, 2, \& 3 (3rd ed.). New York, NY: Cambridge University Press.

Richards, J. C., \& Sandy, C. (2008). Passages 1 \& 2 (2nd ed.). New York, NY: Cambridge University Press.

Rost, M., le Maistre, S., Lewis, C., \& Sharpe, K. (2005). WorldView 1, 2, 3, \& 4. White Plains, NY: Pearson Longman.

Saslow, J. (2001). Workplace plus: Living and working in English 1. White Plains, NY: Pearson Longman. 
Saslow, J. (2002). Workplace plus: Living and working in English 2 \& 3. White Plains, NY: Pearson Longman.

Saslow, J. (2003). Workplace plus: Living and working in English 4. White Plains, NY: Pearson Longman.

Saslow, J., \& Ascher, A. (2006). Top notch fundamentals, 1, 2, \& 3. White Plains, NY: Pearson Longman.

Soars, L., \& Soars, J. (2001). American headway 1 \& 2. New York, NY: Oxford University Press.

Soars, L., \& Soars, J. (2002). American headway starter. New York, NY: Oxford University Press.

Soars, L., \& Soars, J. (2003). American headway 3. New York, NY: Oxford University Press.

Soars, L., \& Soars, J. (2005). American headway 4. New York, NY: Oxford University Press. 